\title{
Rapid transformation of Chlamydomonas reinhardtii without cell-wall removal.
}

\section{AUTHOR(S):}

Yamano, Takashi; Iguchi, Hiro; Fukuzawa, Hideya

\section{CITATION:}

Yamano, Takashi ... [et al]. Rapid transformation of Chlamydomonas reinhardtii without cell-wall removal.. Journal of bioscience and bioengineering 2013, 115(6): 691-694

\section{ISSUE DATE:}

2013-06

URL:

http://hdl.handle.net/2433/174155

\section{RIGHT:}

(C) 2013 The Society for Biotechnology, Japan. Published by Elsevier B.V.; This is not the published version. Please cite only the published version.; この論文は出版社版でありません。引用の際には出版社版を ご確認ご利用ください。 


\section{Title:}

2 Rapid transformation of Chlamydomonas reinhardtii without cell-wall removal

3

\section{Authors:}

5 Takashi Yamano ${ }^{1,2}$, Hiro Iguchi ${ }^{1,2}$, and Hideya Fukuzawa ${ }^{1,2}$ *

$6{ }^{1}$ Graduate School of Biostudies, Kyoto University, Kyoto, 606-8502, Japan

$7 \quad{ }^{2}$ Japan Science and Technology Agency, ALCA, Kyoto, 606-8502, Japan

8

\section{Keywords:}

10 algae; Chlamydomonas reinhardtii; electroporation; square electric pulse;

11 transformation

12

\section{Corresponding author:}

14 Hideya Fukuzawa

15 E-mail: fukuzawa@lif.kyoto-u.ac.jp

16 Tel: $+81-75-753-4298$

17 Fax: $+81-75-753-9228$ 


\section{Abstract}

2 Chlamydomonas reinhardtii is widely used to study many biological processes

3 including biofuel production. Here, we present a rapid transformation technique for

4 cell-walled Chlamydomonas strains without cell-wall removal using a square electric

5 pulses-generating electroporator. This method could be applied to transformation of

6 other industrially useful algae by optimizing the electric conditions. 
1 Chlamydomonas reinhardtii, a single-cell green alga, is widely used for elucidating

2 fundamental biological processes, including photosynthesis, cell cycle regulation, and

3 cell motility as well as metabolic processes for biofuel production because it is

4 relatively easy to transform. Its genome sequence is available (1), and three methods of

5 DNA-mediated transformation have been reported for this organism: bombardment with

6 DNA-coated microprojectiles (2, 3), vortexing with glass beads (4), and electroporation

7 (5). For nuclear genome transformation, the transformation efficiencies of the glass

8 beads method and electroporation are approximately $10^{3}$ and $10^{5}$ transformants per $\mu \mathrm{g}$

9 DNA, respectively (5). However, these procedures require the use of cell-wall-less $(c w)$

10 mutant strains or the removal of cell wall from wild-type cells by treatment with the

11 zinc-containing metallo-protease gametolysin for cell wall degradation $(6,7)$. Both

12 approaches are associated with difficulties: $c w$ mutants are fragile and not suitable for

13 some experiments, such as the measurement of photosynthetic activity, and preparation

14 of gametolysin and removal of the cell wall are time-consuming. To overcome these

15 difficulties, we present here a rapid transformation technique of wild-type

16 Chlamydomonas without cell-wall removal using a square electric pulse generating

17 electroporator, NEPA21 (Nepa Gene, Japan).

18 Although NEPA21 is widely used to transfect animal cells in vivo and in vitro

$19(8,9)$, the electroporator has not been applied to land plants, fungi, and algal cells so far.

20 In contrast to other electroporators, such as Gene Pulser series (Bio-Rad, USA) or ECM

21 series (BTX, USA), NEPA21 has three-step multiple electroporation pulses, resulting in

22 higher transformation efficiency and lower damage to the cells. The first pulse is a

23 poring pulse (Pp) with high voltage and short pulse length. The second pulse consists of

24 multiple transfer pulses (Tp) with low voltage and long pulse length for delivering 
1 exogenous DNA into cells. The third pulse is polarity-exchanged Tp for efficient

2 delivery of DNA molecules into cells. In summary, six parameters, voltage [V], pulse

3 length [msec], pulse interval [msec], number of pulses, decay rates [\%], and polarity,

4 are set for respective $\mathrm{Pp}$ and $\mathrm{Tp}$. In addition, values of electrical impedance between the

5 electrodes $[\Omega]$, actual voltage $[\mathrm{V}]$, current $[\mathrm{A}]$, and energy $[\mathrm{J}]$ can be measured.

7 containing the hygromycin-resistant gene $a p h 7$ " was amplified by PCR from plasmid

8 pHyg3 (10) using PrimeSTAR GXL DNA Polymerase (TAKARA, Japan) using

935 cycles of denaturation for $10 \mathrm{sec}$ at $98^{\circ} \mathrm{C}$, annealing for $15 \mathrm{sec}$ at $60^{\circ} \mathrm{C}$, and

10 extension for $2 \min$ at $68^{\circ} \mathrm{C}$ with a forward primer

11 (5'-GCACCCCAGGCTTTACACTTTATGCTTCC-3') and reverse primer (5'-CCATTCAGGCTGCGCAACTGTTGG-3'). The PCR product was purified using a PCR purification kit (QIAGEN, USA) and the concentration was adjusted to $14200 \mu \mathrm{g} \mathrm{mL} L^{-1}$.

Chlamydomonas reinhardtii strain C-9 (originally provided from the IAM culture collection at the University of Tokyo and kept in our laboratory. C-9 is available

17 from National Institute for Environmental Studies, Japan, as strain NIES-2235) was used as a representative of cell-walled wild-type cells (11). For pre-cultivation, cells were grown in $5 \mathrm{~mL}$ Tris-Acetate-Phosphate (TAP) medium for $\sim 24 \mathrm{~h}$ with vigorous

20 shaking under continuous illumination at $50 \mu \mathrm{mol}$ photons $\mathrm{m}^{-2} \mathrm{~s}^{-1}$. One-day before

21 transformation, $5 \mathrm{~mL}$ of pre-cultured cells was transferred into $100 \mathrm{~mL}$ TAP medium in

22 a $300 \mathrm{~mL}-$ flask and grown for $\sim 24 \mathrm{~h}$. The flask was agitated on a gyratory shaker

$23(100 \mathrm{rpm})$ at $25^{\circ} \mathrm{C}$ under continuous illumination until the cell densities reached $1-2 \times$

$2410^{6}$ cells $\mathrm{mL}^{-1}$, corresponding to an optical density of $0.3-0.4$ at $730 \mathrm{~nm}$. The cultured 
1 cells were collected by centrifugation at $600 \times \mathrm{g}$ for $5 \mathrm{~min}$ and re-suspended in TAP

2 medium containing $40 \mathrm{mM}$ sucrose to a final density of $1 \times 10^{8}$ cells $\mathrm{mL}^{-1}$. Then, $2 \mu \mathrm{L}$

3 of $200 \mu \mathrm{g} \mathrm{mL}^{-1} \mathrm{pHyg} 3 \mathrm{PCR}$ products was added to $38 \mu \mathrm{L}$ of the cell suspension. As a

4 result, $4 \times 10^{6}$ cells and $400 \mathrm{ng}$ DNA were suspended in the total volume of $40 \mu \mathrm{L}$. The

5 cell suspension was placed into an electroporation cuvette with a $2 \mathrm{~mm}$ gap (NEPA

6 GENE, Japan). The measured value of electrical impedance was within 500-600 $\Omega$ in

7 the cell conditions described above. Parameters of Pp were optimized as described

8 below and those of Tp were fixed at a ten polarity-exchanged pulse of $20 \mathrm{~V}$ with

$950 \mathrm{msec}$ pulse length, $50 \mathrm{~ms}$ pulse interval, and a $40 \%$ decay rate.

After electroporation, an aliquot of the cell suspension from the cuvette was

11 transferred into $10 \mathrm{~mL}$ TAP medium containing $40 \mathrm{mM}$ sucrose. After incubation at dim

12 light $\left(2-3 \mu \mathrm{mol}\right.$ photons $\left.\mathrm{m}^{-2} \mathrm{~s}^{-1}\right)$ for $24 \mathrm{~h}$, the cells were collected by centrifugation at

$13600 \times \mathrm{g}$ for $5 \mathrm{~min}$ and plated onto $1.5 \%$ agar TAP plate containing $30 \mu \mathrm{g} \mathrm{mL}^{-1}$

14 hygromycin $\mathrm{B}$. The plate was incubated at $25^{\circ} \mathrm{C}$ under continuous illumination at

$1580 \mu \mathrm{mol}$ photons $\mathrm{m}^{-2} \mathrm{~s}^{-1}$. Colonies of hygromycin-resistant transformants were visible

164 days later.

To determine the optimum transformation conditions, transformation

efficiency as a function of the voltage of $\mathrm{Pp}$ and its pulse length was evaluated. The voltage dependency of transformation with different pulse lengths of 2, 4, 6, and 8 msec

20 were plotted (Fig. 1A). In this experiment, the number of pulses, pulse interval, and

21 decay rates of Pp were kept constant at two pulses, $50 \mathrm{msec}$, and 40\%, respectively. When the Pp was $200 \mathrm{~V}$ and $250 \mathrm{~V}$, maximum transformation efficiency was obtained

23 with an $8 \mathrm{msec}$ pulse length. In contrast, the transformation efficiency with $\mathrm{Pp}=300 \mathrm{~V}$

24 was highest with a $6 \mathrm{msec}$ pulse length and decrease at $8 \mathrm{msec}$, suggesting that cell 
1 damage caused by excess energy with high voltage and long pulse length led to the

2 decrease in efficiency. Next, in order to optimize the levels of energy of the Pp, we

3 evaluated parameters of Pp (Fig. 1B). For instance, energy by two Pps with $50 \mathrm{msec}$

4 pulse length and $40 \%$ decay rates was calculated using following equation,

5

6

7

$$
\text { Energy }=\mathrm{V}_{1 \mathrm{st}} \times 0.05 \times \mathrm{A}_{1 \mathrm{st}}+\mathrm{V}_{1 \mathrm{st}} \times(1-0.4) \times 0.05 \times \mathrm{A}_{2 \mathrm{nd}}
$$

where $V_{1 s t}, A_{1 s t}, A_{2 n d}$ are actual voltage of the first pulse, actual current of the first pulse, and actual current of the second pulse, respectively. Optimal transformation efficiency was obtained with a Pp energy of 1.0-1.5 J. In addition, transformation efficiency was evaluated as a function of the concentration of exogenous DNA (Fig. 1C). With increasing DNA concentrations from 40 to $200 \mathrm{ng}$, the number of transformants increased, reaching a maximum at a concentration of approximately 200-800 ng. Above this DNA concentration, the transformation efficiency decreased. From these results, the final transformation conditions applicable to the Chlamydomonas strain C-9 are summarized in Fig. 1D. The optimal transformation efficiency was obtained by application of two Pps of $250 \mathrm{~V}$ with $8 \mathrm{msec}$ pulse length, 50 msec pulse interval, and $40 \%$ decay rates. Using these conditions, electroporation of $4 \times 10^{6}$ cells $\left(1.0 \times 10^{8}\right.$ cells $\left.\mathrm{mL}^{-1}\right)$ resulted an average of 3,880 transformants per $\mu \mathrm{g}$ DNA for strain C-9 (Table 1, Fig. 2A), which was about 26-fold higher than the 150 transformants per $\mu \mathrm{g}$ DNA for strain C-9 strain with the previous electroporation procedure without cell-wall removal.

Transformation efficiency of cell-wall removed C-9 was also examined.

Under optimal electric conditions described above, electroporation of cell-wall removed C-9 resulted an average of 2,702 transformants per $\mu \mathrm{g}$ DNA. In contrast, the transformation efficiency increased 2.8 times to 7,614 transformants per $\mu \mathrm{g}$ DNA by 
1 application of two Pps of $200 \mathrm{~V}$ with $5 \mathrm{msec}$ pulse length, $50 \mathrm{msec}$ pulse interval, and

$240 \%$ decay rates, suggesting that high voltage and long pulse length led to cell damage

3 for cell-wall removed C-9 and the decrease in efficiency.

To examine whether this method is applicable to other cell-walled wild-type

5 Chlamydomonas strains, we evaluated the transformation efficiency of strains CC-124,

6 CC-125, and CC-1690 using the same electroporation conditions (Table 1). Although

7 the transformation efficiencies of CC-124 (2,930 \pm 471 cells) and CC-1690 (3,400 \pm

8327 cells) were similar or slightly decreased compared to that of C-9 (3,880 \pm 470 cells),

9 the efficiency with strain CC-125 was only $10 \%$ (404 \pm 37 cells) of that of C-9.

10 However, changing the Pp to one pulse of $300 \mathrm{~V}$ with an $8 \mathrm{msec}$ pulse length resulted in

11 an increase in the transformation efficiency to $1,920 \pm 110$ cells per $\mu \mathrm{g}$ DNA. In those

12 conditions, energy of one Pp was $1.23-1.31 \mathrm{~J}$, which is in the range of optimum energy

13 (1.0-1.5 J) of two Pps (Fig. 1B), suggesting that larger energy is needed to induce pore

14 formation for strain CC-125 compared to other wild-type strains.

In addition, we could introduce a longer plasmid, pTT1-LciB-GFP (12), with

16 the length of 7,800-bp into C-9 cells without removal of the cell wall. Although the

17 transformation efficiency was $~ 500$ transformants per $\mu \mathrm{g}$ DNA, LCIB-GFP localization

18 could be observed in the transformed cells (Fig. 2B).

19 In previous methods, it takes at least several days for preparation of the

20 gametolysin before the transformation. In contrast to that, cell-walled strains can be

21 directly transformed by DNA without any preparation or cell-wall removal using this

22 method. Additionally, by optimizing the electric conditions, the square electric pulse

23 generating electroporator could be applied to transformation of other industrially useful

24 algae. 
We thank Dr. Kentaro Ifuku (Kyoto university) and Mr. Yasuhiko Hayakawa

2 (Nepa Gene Co., Ltd.) for helpful discussions and suggestions. This research was

3 supported by JST, ALCA.

4

$5 \quad$ References

1. Merchant, S., Prochnik, S., Vallon, O., Harris, E., Karpowicz, S., Witman, G., authors: The Chlamydomonas genome reveals the evolution of key animal and plant functions. Science, 318, 245-250 (2007).

2. Boynton, J., Gillham, N., Harris, E., Hosler, J., Johnson, A., Jones, A., Randolph-Anderson, B., Robertson, D., Klein, T., Shark, K., and Sanford, J.: Chloroplast transformation in Chlamydomonas with high velocity microprojectiles.

3. Blowers, A., Bogorad, L., Shark, K., and Sanford, J.: Studies on Chlamydomonas Science, 240, 1534-1538 (1998). chloroplast transformation: foreign DNA can be stably maintained in the

4. Kindle, K.: High-frequency nuclear transformation of Chlamydomonas reinhardtii. Proc. Natl. Acad. Sci. USA, 87, 1228-1232 (1990).

5. Shimogawara, K., Fujiwara, S., Grossman, A., and Usuda, H.: High-efficiency transformation of Chlamydomonas reinhardtii by electroporation. Genetics, 148, 1821-1828 (1998).

6. Kinoshita, T., Fukuzawa, H., Shimada, T., Saito, T., and Matsuda, Y.: Primary 
1 similarity of functional domains to matrix metalloproteases. Proc. Natl. Acad. Sci.

$2 \quad$ USA, 89, 4693-4697 (1992).

3 7. Kubo, T., Saito, T., Fukuzawa, H., and Matsuda, Y.: Two tandemly-located

4 matrix metalloprotease genes with different expression patterns in the

$5 \quad$ Chlamydomonas sexual cell cycle. Curr. Genet., 40, 136-143 (2001).

6 8. Miyata, S., Komatsu, Y., Yoshimura, Y., Taya, C., and Kitagawa, H.: Persistent

7 cortical plasticity by upregulation of chondroitin 6-sulfation. Nat. Neurosci., 15,

$8 \quad 414-422(2012)$

9 9. Kusuzawa, S., Honda, T., Fukata, Y., Fukata, M., Kanatani, S., Tanaka, DH., 10 and Nakajima, K.: Leucine-rich glioma inactivated 1 (Lgi1), an epilepsy-related 11 secreted protein, has a nuclear localization signal and localizes to both the cytoplasm and the nucleus of the caudal ganglionic eminence neurons. Eur. J. Neurosci., 36, 2284-2292 (2012).

10. Berthold, P., Schmitt, R., and Mages, W.: An engineered Streptomyces hygroscopicus aph 7" gene mediates dominant resistance against hygromycin B in Chlamydomonas reinhardtii. Protist, 153, 401-412 (2002).

11. Harris, E.: The genus Chlamydomonas, p. 1-24. In Harris, E., Stern, D., Witman, J. (eds), The Chlamydomonas Source Book, vol. 1. Elsevier, Amsterdam (2009).

12. Yamano, T., Tsujikawa, T., Hatano, K., Ozawa, S., Takahashi, Y., and Fukuzawa, H.: Light and low- $\mathrm{CO}_{2}$-dependent LCIB-LCIC complex localization in the chloroplast supports the carbon-concentrating mechanism in Chlamydomonas reinhardtii. Plant Cell Physiol., 51, 1453-1468 (2010). 


\section{$1 \quad$ Figure legends}

2 Fig. 1 (A) Effects of voltage of Pp and pulse length on transformation efficiency. The

3 number of transformants per $\mu$ g DNA was plotted at voltages of 200,250 , and $300 \mathrm{~V}$

4 with different pulse length; $2 \mathrm{msec}, 4 \mathrm{msec}, 6 \mathrm{msec}$, and 8 msec. (B) Relationship

5 between energy of Pp and transformation efficiency. Each white circle represents the

6 data from one experiment. (C) Effect of DNA concentration on transformation

7 efficiency. Strain C-9 was transformed with the indicated concentrations of pHyg3 PCR

8 product. (D) Schematic of electric pulses delivered by NEPA21. Assignable parameters

9 are represented. $\mathrm{Pp}, \mathrm{Tp}$, and polarity-exchanged Tp are shown as black, white, and gray

10 bars, respectively. Optimal transformation parameters applicable to strain C-9 are

11 indicated.

13 Fig. 2 (A) Colonies of hygromycin-resistant transformants plated on TAP agar medium

14 containing $30 \mu \mathrm{g} \mathrm{mL}^{-1}$ hygromycin B. (B) Fluorescent signal of LCIB-GFP derived

15 from transformants with the pTT1-LciB-GFP plasmid using NEPA21. Obvious ring

16 fluorescence signals are present around the pyrenoid structure, as previously shown (12).

17 White bar is $5 \mu \mathrm{m}$. 
Fig. 1

A
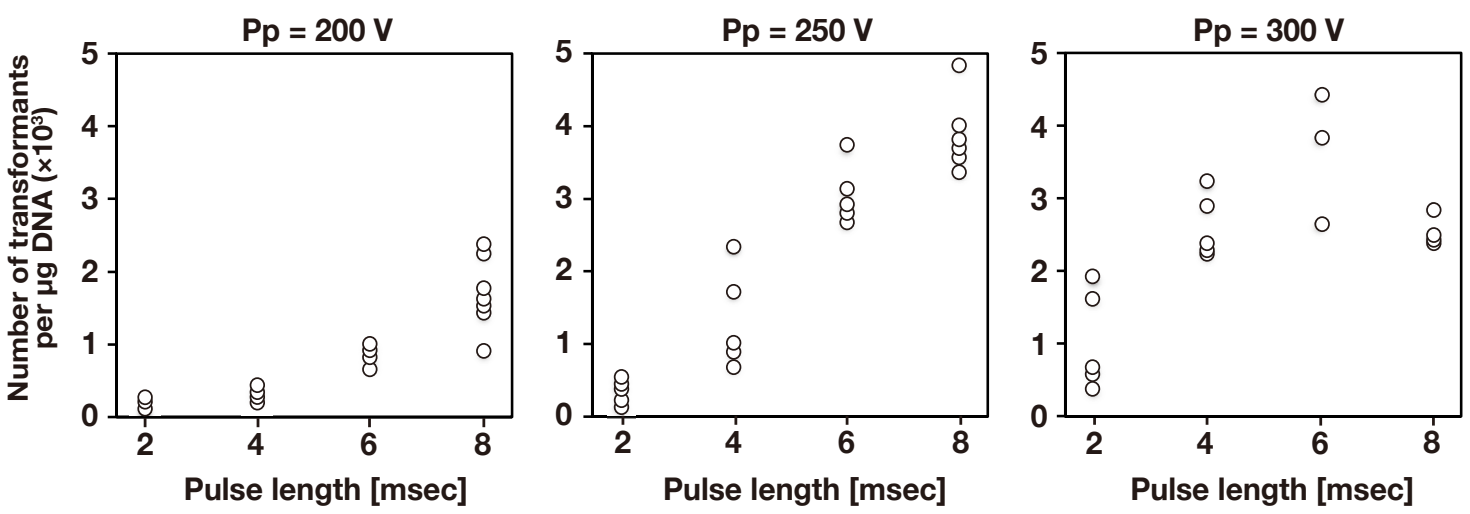

B
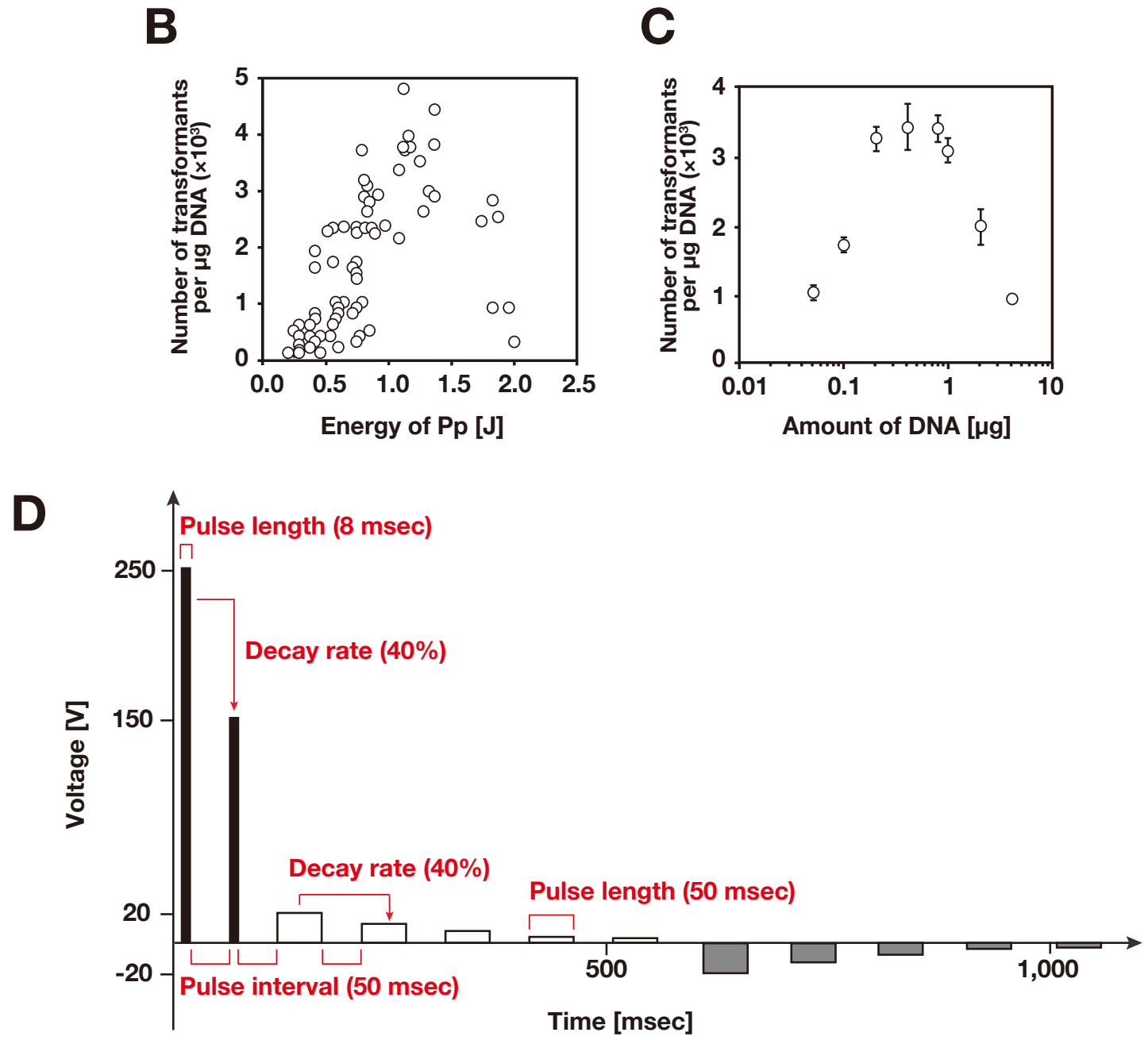
Fig. 2

A

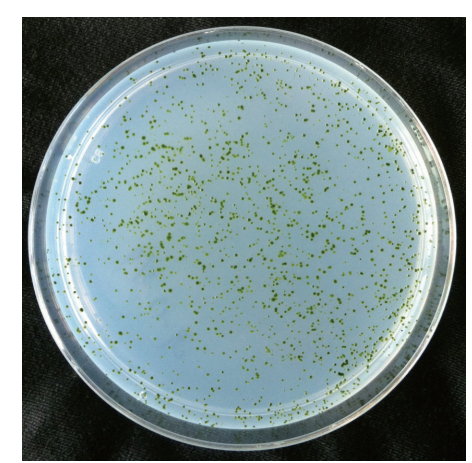

B

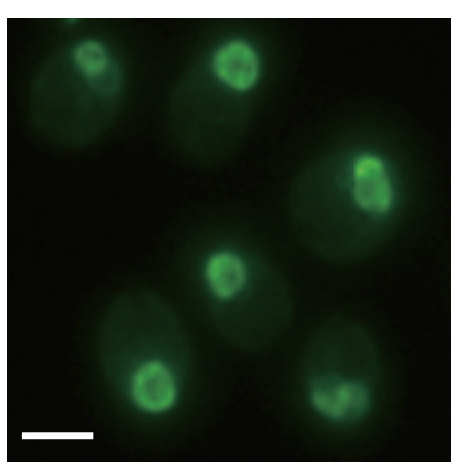


Table 1. Transformation efficiency of various Chlamydomonas strains using NEPA21

\begin{tabular}{|c|c|c|c|c|}
\hline $\begin{array}{l}\text { Device used for } \\
\text { electroporation }\end{array}$ & Strain & $\begin{array}{c}\text { Cell wall degradation by } \\
\text { gametolysin }\end{array}$ & Electric conditions of $\mathrm{Pp}$ & $\begin{array}{c}\text { Number of transformants } \\
\text { per } \mu \mathrm{g} \text { DNA }\end{array}$ \\
\hline \multirow{7}{*}{ NEPA21 (NEPA GENE) } & C-9 & - & $\begin{array}{l}\mathrm{V}_{1 \mathrm{st}}: 250 \mathrm{~V} \text { for } 8 \mathrm{msec} \\
\mathrm{V}_{\text {2nd }}: 150 \mathrm{~V} \text { for } 8 \mathrm{msec}\end{array}$ & $3,880 \pm 470$ \\
\hline & C-9 & + & $\begin{array}{l}\mathrm{V}_{1 \mathrm{st}}: 250 \mathrm{~V} \text { for } 8 \mathrm{msec} \\
\mathrm{V}_{\text {2nd }}: 150 \mathrm{~V} \text { for } 8 \mathrm{msec}\end{array}$ & $2,702 \pm 303$ \\
\hline & C-9 & + & $\begin{array}{l}\mathrm{V}_{1 \mathrm{st}}: 200 \mathrm{~V} \text { for } 5 \mathrm{msec} \\
\mathrm{V}_{\text {2nd }}: 120 \mathrm{~V} \text { for } 5 \mathrm{msec}\end{array}$ & $7,614 \pm 693$ \\
\hline & CC-124 & - & $\begin{array}{l}\mathrm{V}_{1 \mathrm{st}}: 250 \mathrm{~V} \text { for } 8 \mathrm{msec} \\
\mathrm{V}_{\text {2nd }}: 150 \mathrm{~V} \text { for } 8 \mathrm{msec}\end{array}$ & $2,930 \pm 471$ \\
\hline & $\mathrm{CC}-125$ & - & $\begin{array}{l}\mathrm{V}_{1 \mathrm{st}}: 250 \mathrm{~V} \text { for } 8 \mathrm{msec} \\
\mathrm{V}_{\text {2nd }}: 150 \mathrm{~V} \text { for } 8 \mathrm{msec}\end{array}$ & $404 \pm 37$ \\
\hline & CC-125 & - & $300 \mathrm{~V}$ for $8 \mathrm{msec}$ & $1,920 \pm 110$ \\
\hline & CC- 1690 & - & $\begin{array}{l}\mathrm{V}_{1 \mathrm{st}}: 250 \mathrm{~V} \text { for } 8 \mathrm{msec} \\
\mathrm{V}_{\text {2nd }}: 150 \mathrm{~V} \text { for } 8 \mathrm{msec}\end{array}$ & $3,400 \pm 327$ \\
\hline Gene-Pulser (Bio-Rad) & C-9 & - & $300 \mathrm{~V}$ & $150 \pm 25$ \\
\hline
\end{tabular}

To match the experimental conditions, carrier DNA or starch embedding methods (5) was not used for either transformation procedure. The amount of exogenous DNA and the number of cells for each transformation were constant at $400 \mathrm{ng}$ and $4.0 \times 10^{6}$ cells, respectively. $\mathrm{V}_{1 \mathrm{st}}$ and $\mathrm{V}_{2 \mathrm{nd}}$ are first and second poring pulse, respectively. 